University of Nebraska - Lincoln

DigitalCommons@University of Nebraska - Lincoln

H. W. Manter Laboratory Library Materials

3-1924

\title{
The Hemotoxins of Intestinal Parasites: A Critical Summary with Notes of Some Cases
}

Joseph Mellick Leidy II

Swarthmore College

Follow this and additional works at: https://digitalcommons.unl.edu/manterlibrary

Part of the Parasitology Commons

Leidy, Joseph Mellick II, "The Hemotoxins of Intestinal Parasites: A Critical Summary with Notes of Some Cases" (1924). H. W. Manter Laboratory Library Materials. 25.

https://digitalcommons.unl.edu/manterlibrary/25

This Article is brought to you for free and open access by DigitalCommons@University of Nebraska - Lincoln. It has been accepted for inclusion in H. W. Manter Laboratory Library Materials by an authorized administrator of DigitalCommons@University of Nebraska - Lincoln. 


\section{THE HEMOTOXINS OF INTESTINAL PARASITES. A CRITICAL SUMMARY WITH NOTES ON SOME CASES \\ JOSEPH LEIDY II \\ PHILADELPHIA}

The mechanical and reflex disturbances produced by animal parasites in the intestinal canal and other organs of the body have long been recognized by pathologists and clinicians. The researches of economic parasitologists and the occasional reports by clinical observers indicate the presence of other factors deserving of further investigation. That certain parasitic worms secrete substances that effect the blood of their hosts deleteriously has been shown conclusively by the researches of Tallqvist, Schwartz, Schaumann and others. The broad tapeworm of man which is known to produce severe anaemia contains a hemolytic agent according to the experiments and researches of Schaumann and Tallqvist. Hookworms secrete a hemolysin and an anticoagulin according to Calmette and Breton, Loeb and Smith. The whipworm Trichuris apparently secretes a hemolysin according to the investigations of Whipple (1909) and Sarin (1913).

In 1865 Kuttner cites a case of blood destruction cured by expelling ascarides. According to Filatoff (1897) Karaven cured a case of pernicious anemia by expelling ascarides from the intestine. Francois (1906) in the course of his investigation of miners found many cases of severe anemia in which hookworms were not present, but which showed numerous ascaris eggs in the feces, and Schwartz has shown that the anemia in hogs and horses is frequently associated with Ascaris lunbricoides infection. Two views as to the cause of parsitic anemia have been held by different authorities. One that the anemia results from depriving the host of blood by sucking the other through the secretion of a hemolysin, a hemotoxin hemolytic in character. Owing to the fact that the abstraction of blood by parasites appears to be inadequate as an explanation of the causes of anemia in parasitic diseases. and in tapeworm infections due entirely to the presence of parasites, the direct abstraction theory as applied to hookworm anemia is inapplicable. From the researches of Schwartz and others the view that hemolysins from parasites are of etiological significance in parasitic diseases appears to be entirely justified.

Huber (1870) expressed the opinion that many symptoms put down to round worms are caused by a peculiar irritating matter which they

Read before the Section on Medicine, College of Physicians, Philadelphia. Feb. 26, 1923. 
contain. Huber draws attention to the observation of Mirams that the examination of Ascaris megalocephala had twice caused him most unpleasant symptoms such as sneezing, swelling at the puncta lachrymalis, hypersecretion of tears with violent itching and swelling of the fingers. Huber states after a personal examination of twelve examples of Ascaris lumbricoides he suffered from troublesome itching of the hand and neck; over the latter the skin was raised here and there in lumps, smaller lumps appearing on the forehead. His right ear swelled up and for an hour a plentiful secretion came from the meatus associated with a most unpleasant sensation of pulsation in the right side of the head radiating from the ear. His conjunctiva became inflamed, accompanied with severe itching, the inflammation leading to chemosis in the right eye and finally itching of the hands. After the lapse of an hour these symptoms gradually subsided. Huber considers that these symptoms were caused by the peculiar substance which gives off the strong smell peculiar to round worms, and which as Leuckart supposes is contained in the vacuoles between the muscular fibers. In 1898 Schaumann and Tallqvist reported the discovery of a blood toxin in the broad tapeworm of man; four years later, 1902, Schimmelpfennig announced that the symptoms produced by the horse ascaris were due to a hemotoxin. He observed in the presence of the coelomic fluid of Ascaris equorum, red blood cells from the horse became cremated and were ultimately destroyed through a process hemolytic in character. It should be stated, however, in this research of Schimmelpfennig no mention of the percentage of alkalinity of the coelomic fluid is given.

Anemia has been frequently associated with the ascarides in both man and animals and the literature reveals the fact that this anemia has been mistaken for hookworm and pernicious anemia. The researches of Faust, Beumer, Dascotte, cited by Weinburg, Calamida, Kolmer, and more recently Ransom and others indicates the importance of a closer study by clinicians of these problems which have been confined more particularly to medical and economic zoologists. It has been shown that Diphyllobothrium latum, the broad tapeworm of man, is capable of causing severe anemia clinically indistinguishable in the opinion of various observers from pernicious anemia and according to these investigators differing from the former in one respect only, namely, by the disappearance of the symptoms and recovery of the patient after expulsion of the parasites. On the other hand there are numerous cases on record in which the presence of Diphyllobothrium latum in man was not accompanied by anemia. What then is the explanation of the immunity noticeable in one group of cases not present in the others? Schwartz has shown that the serological reaction of the hosts harboring parasites afford proof that parasitic worms liberate products against which the hosts develop defense or immunity reactions. Kolmer, Trist 
and Heist according to the results of complement-fixation tests with the sera of infested dogs had reason to believe that production of antibodies may occur after infestation of the intestines with the common parasites.

Worms belonging to the genus Ascaris contain a hemolysin which is closely bound to the muscle tissues of the worm and is but slightly soluble in water (Schwartz). Other observers are of the opinion the toxin is given off from other structures and organs. Can it be in the former case one finds an explanation of the immunity of the host in those cases where there is an absence of profound constitutional disturbance? The ascarides appear also to secrete a feeble anticoagulin. In a series of experiments in vitro Schwartz found that extracts of the intestines of parasites were strongly hemolytic, whereas extracts from the body wall showed no hemolytic effect. Extracts of the reproductive organs were but moderately hemolytic. In a second series of experiments extracts of the intestines were strongly hemolytic whereas extracts of the reproductive organs and body wall showed weak hemolytic powers.

The present note has to do with the results of a clinical study of three cases of parasitic infection which have come under the author's observation and points strongly to the hemotoxin of the ascarides as an etiological factor deserving of attention.

CASE 1.-Female, aged 12, applied for treatment April, 1921.

Four years previously suffered from corneal ulcers and malnutrition which illness covered a period of from five to six months; the corneal condition was markedly resistant to treatment so much so that the case was looked upon as one of incipient tuberculosis. The mother reports after six months' illness the child suddenly began to improve without apparent cause and in a very short time had recovered her former good health. The patient was referred to me as one of possible incipient tuberculosis. The corneal condition which had recurred was under the care of Dr. E. S. Saylor. The child was poorly nourished, there was loss of weight and color, from an active cheerful disposition, the patient was depressed, indisposition to play or take interest in her toys or books. Examination of the heart, lungs and genito-urinary tract proved negative. Blood examination: Hemoglobin, 70 per cent.; eosinophils, 14 per cent. Gastro-intestinal tract: Mother reports four years previously the child had passed a large number of dead worms, very offensive. She had administered a "worm medicine" purchased as a proprietary medicine when she detected the parasites in the stools but had not reported the fact to the attending physician. With this history taken in connection with the high eosinophil count (14 per cent.) santonin was administered which was followed by the expulsion of a coil of twelve worms to be followed in six hours by the expulsion of four worms all dead and presenting the appearance of being partially digested and decomposed.

The patient made a prompt and uninterrupted recovery. She is now in full vigor of health, blood count normal, no ova in stools and increased (21) twenty-one pounds in weight. The rapid recovery from both of these attacks following the expulsion of disintegrated or partially digested worms is significant.

CASE 2.-L. R., male, aged 9.

With chronic eczema of eight months' duration, occasional epistaxis, and malnutrition. The patient had run the gauntlet of local and constitutional treat- 
ment, physical examination of heart, lungs and genito-urinary tract negative; urine showed increase in indican, no increase in sulpho-ethers; microscopic examination of feces showed the presence of large numbers of ova of ascarides. Treatment: santonin was administered followed by the expulsion of twenty round worms, in one coil; there were three dead, disintegrated and partially digested. The day following the expulsion of the parasites the eosinophil count was 16 per cent.; hemoglobin, 70 per cent. Three months later the patient was free from all evidence of eczema; eosinophil count, 3 per cent. The patient is now well ten months after infection was discovered.

D. T. R. Brown in Johns Hopkins Hospital Reports cites a case of chronic eczema with an eosinophil count of 22 per cent. but no reference is made to the condition of the gastro-intestinal tract or results of treatment.

CASE 3.-I saw in consultation with Dr. R. E. Brown of New York, March 3, 1911, male, aged 5. The subject of frequent attacks of angioneurotic edema, the symptoms were alarming to the family and attendants, the case presented a classical picture of the condition. Blood examination two weeks previous to consultation: esosinopils, 10 per cent.; hemoglobin, 70 per cent.

The condition was viewed as one of intestinal toxemia; there was no increase either of indican or sulpho-ether excretion. Microscopic examination of feces showed large numbers of ova of ascarides. The administration of santonin was followed by the expulsion of twenty-six round worms, many dead disintegrated or partially digested. There has been no recurrence of the attacks in twelve years. The boy. is now in perfect health.

Intestinal toxemia is not unfrequently an etiological factor in cases of angioneurotic edema, but in all those cases which have come under observation of the writer the indican content of the urine ran high with an appreciable increase in the elimination of the sulphoethers and in no case was there an increase in the eosinophil count. The fact that in the cases reported three or more of the parasites were dead and showed evidence of having undergone decomposition, disintegration and partial digestion by the host is significant. To what extent hemotoxic substances are liberated when the parasites sicken or undergo degeneration deserves more extended investigation. In the case of the broad tapeworm, Diphyllobothirium latum, it appears highly probable the observation as pointed out by Schwartz that certain individuals may lack antilytic constituents in the blood and are thus susceptible to the toxin which other individuals are capable of neutralizing, may prove correct. On the other hand that parasites may die and undergo disintegration before elimination by the host is made clear from the cases cited.

Leidy (1849) demonstrated that parasitic worms while living within the host may harbor vast quantities of cryptogamic vegetation with a great variety of species of entophyta growing upon the surface of the living parasite. Weinburg described what appears to be a disease in worms belonging to the genus Ascaris, which is characterized by the presence of certain pigmented spots visible through the cuticula. This condition has also been observed by Schwartz. It would appear from these observations that both causes acting together or independent of the other may prove to be the prime etiological factor in the production 
of a group of symptoms which were formerly attributed to mechanical or reflex phenomena. The presence of a high eosinophil count in the peripheral blood is generally considered presumptive evidence of parasitic infection by helminthologists. The literature has become extensive and with a long list of observers leaning strongly to the presence of hemotoxins as etiological factors in a group of symptoms which have been hitherto clustered under the shield of mechanical or reflex phenomena a new field is open for further investigation which bids fair to place what may be termed the parasitic syndrome as applied to intestinal parasites upon a workable scientific basis.

In view of the results obtained from the surveys made in our army camps for hookworm and allied parasites all cases especially among young children and adolescents presenting the picture of malnutrition, anemia with or without increase in the eosinophil count should be viewed with suspicion as being the subject of parasitic infection and a microscopic examination of the feces be made to determine the presence or absence of parasitic ova ; indeed the time has arrived when the examination of the feces should be as much a matter of routine as the examination of the urine. In any health survey of school children the microscopic examination of the feces should become a part of the physical examination as was pursued in army camps during the World War.

BIBLIOGRAPHY

Brown, T. R. 1898.-Studies on Trichinosis, with Especial Reference to the increase of the Eosinophilic Cells in the Blood and Muscle, the Origin of these Cells and their Diagnostic Importance. Jour. Exp. Med., 3:315-348.

Calamida, Dante. 1901.-Weitere Untersuchungen über das Gift der Tänien. Centb1. Bakt., Abt. 1, 30:374-375.

Calmette, A., and Breton, M. 1905.-L'ankylostoma. L'ankylostomiase. Paris. $246 \mathrm{pp}$.

Filatoff, N. F. 1897.-Vers intestinaux. In Traité des maladies de l'enfance de J. Graucher, J. Comby. Paris. Pp. 670-698.

Francois, E. 1906.-Anemie des mineurs. Paris. 122 pp.

Garin, Charles. 1908.-Trichocêphale gorgê de Sang. Lyon Med., 11: 383.

1913.- Recherches physiologiques. Ann. Univ. Lyon, n.s. I, sci. med. fasc. 34.

Guiart, Jules. 1914.-Biologie et role pathogene des parasites animaux. In Bouchard and Roger, Nouveaux Traité de Pathologie Générale, 2: 83-973.

Huber,. J. 1870.-Parasites. Ziemssen Encylopedia, 7:74.

$\rightarrow$ Kolmer, J. A., Trist, M. E., and Heist, G. D. 1916.-Complement Fixation in Intestinal Parasitism. Jour. Infect. Dis., 18: 88-105.

Kuttner. 1865.-Mesenterial-neuralgie mit Fieber. Berl. klin. Wchnschr. $2: 308-309$.

Loeb, Leo, and Smith, A. J. 1904.-The Presence of a Substance Inhibiting the Coagulation of the Blood in Anchylostoma. Proc. Path. Soc. Phila., n. s., 7: 173-177.

Leidy, Joseph. 1850.-Germs Living Within the Intestinal Canal of the Lower Animals. Proc. Acad. Nat. Sci. Phila., Oct., 1849; Jan., 1850.

1853.-Flora and Fauna Within Living Animals. Smithsonian Contrib. Know1., 5, Art. 2, 67 pp.

Ransom, B. H. 1922.-Observations on the Toxic Effects of Ascaris Fluids. Jour. Parasit., 9: 42-43. 
Schaumann, Ossian. 1898.-Ueber die Blutkörperchen auflösenden Eigenschaften des breiten Bandwurms. Deut. med. Wchnschr., 24:312-313.

Schimmelpfennig, Gustav. 1902.-Ueber Ascaris megalocephala. Beitr. Biol. u. physiol. Chemie derselben, 46-49. Inaug. Diss., Berlin.

Schwartz, Benjamin. 1921.-Hemotoxins from Parasitic Worms. Jour. Agric. Res., $32: 8$.

Tallqvist, T. W. 1907.-Zur Pathogenese der perniciösen Anämie mit besonderer Berücksichtigung der Bothriozephalus-anämie. Ztschr. klin. Med., Berl., $61: 427-532$.

Weinburg, M. 1907.-Sur une hemotoxine d'origine vermineuse. Compt, rend. soc. biol. Paris, $63: 13-15$.

1911.-Substances toxiques de l'Ascaris megalocephela. Compt. rend. soc. biol., Paris, $70: 337-339$.

1912.-Une maladie de l'Ascaris megalocephala. Compt. rend. soc. biol., Paris, $73: 260-262$. 